\title{
A Concept for Project Manufacturing Planning and Control for Engineer-to-Order Companies
}

\author{
Pavan Kumar Sriram, Erlend Alfnes, and Emrah Arica \\ Norwegian University of Science and Technology, Trondheim, Norway \\ \{Pavan.sriram, erlend.alfnes, emrah.arica\}@ntnu.no
}

\begin{abstract}
Engineer-to-order products are customized to a particular client's specification. Planning can be a problem as the products may be large and complex especially due to uncertainties in the duration of the operations. A conceptual project manufacturing planning and control (PMPC) framework is presented in relation to typical engineer to order (ETO) companies. The existing approaches, problems, solutions, and limitations of current manufacturing planning and control (MPC) for ETO environment are discussed. This paper contributes to the development of an improved understanding and more robust definition of MPC in ETO industries, and highlights how the key challenges and the opportunities that PMPC offer in an ETO sector.
\end{abstract}

Keywords: engineer to order, project manufacturing planning and control.

\section{Introduction}

ETO supply networks are dynamic and hard to define, and their planning and control functionalities are frequently affected by the actions of suppliers and customers which typically may result in excessive inventories, long lead times, low customer satisfaction and poor resource allocation [5]. Due to high complexity of the products the customer are involved closely from the design to engineering phase of a product [3]. ETO companies cannot forecast due to unknown sales and product specifications for future order [5]. This type of manufacturing environment requires a modified manufacturing planning and control (MPC) method to suit the characteristics and in this paper we highlight and discuss some of the classical MPC approaches such as Kanban, Manufacturing Resource approaches' to Production Planning (MRP II) and Theory of Constrains (TOC), and also discuss techniques such as Workload Control (WLC), Constant Work In Process (CONWIP), Paired cell Overlapping Loops of Cards with Authorization (POLCA) solutions for their applicability for ETO [15]. The paper starts with a description of the methodology, followed by an introduction to the empirical background of ETO. Next, MPC is defined, while the two subsequent sections outline and discuss issues on the current MPC approaches and its limitations and Project manufacturing planning and control (PMPC) respectively. The conclusion outlines the paper's contributions and some suggestions for further research. 


\section{Methodology}

This conceptual paper is a theoretical discussion of the MPC approaches applicable to an ETO environment. Research on the ETO MPC approaches situations is scarce since the majority of research focuses on a mass production environment. The paper's theoretical base is within planning and control, and the discussion exploits on improving the existing MPC system proposed by Vollmann [19] through recommendations that have been carefully identify by the literature review in the form of international journal publications, scientific textbooks, and white papers in order to capture the main challenges, approaches and solutions from previous researchers on the MPC in ETO sector. The aim of the paper is therefore not to provide solutions to these highly complex issues, but rather to highlight, discuss and develop a PMPC framework based on existing literature.

\section{ETO Sector Characteristics and Requirements}

ETO companies are characterized by time-limited projects related to the supply of complex equipment to third parties, and this process often includes the phases: design, manufacturing, installation, and commissioning [16] and [3] state that that the coupling point is located at the design stage, and operate in project specific environments. According to Hicks [7] ETO products are manufactured and assembled in low volumes to satisfy individual customers' specifications. Stevenson et al., [15] agrees on this and described the production volume as batch of one to very low volume. The production volume is not mention by all authors but there is no disagreement found in literature that the production volume is low within the ETO environment. Bertrand and Muntslag [2] describe control characteristics of the ETO production situation by using the following three aspects: dynamics, uncertainty and complexity. The engineer-to order firms have to cope with strong fluctuations in mix and sales volume in the short and medium term. It is impossible to cope with these fluctuations by means of, for example, creating capacity stock because of the customer order driven production. This dynamic market situation asks for a lot of flexibility to cope with these fluctuations. Gosling and Naim [3] and Little [11] describe that flexibility is a condition for ETO firm success, an ETO company needs to deal with strong fluctuations in mix and sales volume. The second characteristics uncertainty is the difference between the amount of information required to perform a task and the amount of information already available in the organization. And in an ETO environment uncertainty is high for both the process as for the products for example in terms of specification, demand, lead times and the duration of processes [5] The third characteristic mentioned by Bertrand and Muntslag [2] is complexity and it exists because information is unknown and changes are bound to occur over time. Little [11] states that a common feature of ETO manufacturing is for the customers to change their requirements over the time of the production. 


\section{$4 \quad$ ETO MPC Approaches and Exiting Solutions}

Classical manufacturing planning and control methods such as Material Requirement Planning, Workload Control, Drum-Buffer-Rope, Kanban and CONWIP are briefly described on the next pages. At the end of this description the characteristics of the methods are summarized in Table 2 .

Material Requirements Planning (MRP) and Manufacturing Resource Planning MRP II: MRP is a periodic push-based system designed for complex production planning environments [15]. In a study of Sower and Abshire [13] was found that one-third of the manufacturing companies studied use packages such as MRP. MRP II often offers greater functionality then MRP because of the wider integration of the number of modules and company operations. According to [3] the choice of a MRP II system is often based on the wide availability. They also state that many engineer-toorder firms have tried to implement MRP II without success.

Workload Control (WLC): is a MPC method designed for highly complex production environments like job shop and MTO / ETO industry. Land and Gaalman [10] mention that WLC works particularly well in the job shop environment, reducing shop floor throughput time (SFTT) and WIP. According to Stevenson and Hendry [16] WLC originates from the concept of input and output control. The input of work to the shop floor is controlled in agreement with the capacity of work centres (the output rate) in order to regulate and maintain a stable level of WIP. The method Workload Control will not be simulated, not because it doesn't fit an engineer-toorder environment well but because this method needs to be included in the demand planning at the medium planning level horizon.

Drum-Buffer-Rope (DBR): The Theory of Constraints (TOC) is a bottleneckoriented concept which is developed from Optimized Production Technology (OPT), as is commonly attributed to the work of Goldratt [16] The production planning and control method is now more known as the Drum-Buffer- Rope (DBR) approach. Under the TOC philosophy, the bottleneck should be scheduled at $100 \%$ utilisation because the bottleneck determines the performance of the whole production system. The bottleneck work centers are the drums and are used to control the workflow. The rope refers to "pull" scheduling at the non-bottleneck work centers. The purpose of the rope is to tie the production at each resource to the drum. The buffers are used to protect the throughput of the bottleneck work centers. The goal of the DBR method is to break a constraint, or bottleneck condition, and thereafter identify the next constraint. This continuous improvement process is an integral part of the TOC philosophy [19]. Wahlers and Cox [20] highlight the applicability to highly customized industries where the companies where able to reduce the lead time and improve the delivery reliability performance.

KANBAN: Kanban is a card-based production system where the start of one job is signalled by the completion of another. According to Stevenson et al. [15] there are many variations of the Kanban system but in the simplest form cards is part number specific. Kanban is not a suitable method within the engineer-to-order environment because of the routing variability, small batch size and lack of repetitions. 
POLCA: POLCA is an abbreviation for Paired-cell Overlapping Loops of Cards with Authorization [18]. It is a MPC method that regulates the authorization of order progress on the shop floor in a cellular manufacturing system. POLCA controls the flow of work between production cells. The method is introduced by Suri [18] in his book on Quick Response Management (QRM). Within this management philosophy the focus is on the reduction of lead time.

CONWIP: CONWIP stands for Constant Work In Progress and is a continuous shop floor release method. The CONWIP system has been proposed in [13], and further presented in [14]. CONWIP uses cards to control the number of WIPs. For example, no part is allowed to enter the system without a card (authority). After a finished part is completed at the last workstation, a card is transferred to the first workstation and a new part is pushed into the sequential process route. Spearman et al. [13] mention that CONWIP sets a limit on the total WIP in the entire system. CONWIP and Kanban are both card systems but Kanban sets a limit on the number of jobs between every pair of adjacent stations. Rather than set a limit on the level of WIP between each step in the manufacturing process, or the entire system. Hopp and Roof [9] mention that to change the number of cards and regulates the level of WIP Statistical Throughput Control is used. This requires accurate feedback data which is difficult to provide in a complex manufacturing environment like ETO.

In table 1 all the described manufacturing planning and control methods are summarized. For each method the characteristics are summed up. It is important when using these methods to be aware of this and take it into consideration when selecting a MPC method for an engineer-to order organization.

Table 1. MPC method characteristics

\begin{tabular}{|l|c|c|c|c|}
\hline MPC method & Push or Pull & Product mix & Volume & Flexibility \\
\hline MRP \& MRP II & Push & Stable & High & Low \\
\hline WLC & Pull & Variable & High & High \\
\hline DBR & Hybrid & Stable & Low & Low \\
\hline Kanban & Pull & Stable & High & Low \\
\hline POLCA & Hybrid & Variable & Low & High \\
\hline CONWIP & Hybrid & Stable & Low & High \\
\hline
\end{tabular}

Based on the description and summary we can see that WLC and POLCA have some degree of relevance towards planning and control activities in an ETO and others lack the capability to meet the requirements of an ETO environment. As of now there is only one framework common to all types of manufacturing and due to issues such as demand forecast, short lead time and urgent delivery, controlling engineering change, dynamic scheduling and coordination of activities etc. calls for a modified MPC framework as even the approaches like WLC and POLCA might not be the most efficient approaches [15] to meet the overall requirement of ETO characteristics. Table 2 shows the summary of manufacturing planning and control literature in ETO reviewed. And based on the summary and discussions we propose PMPC which is described in the next section. 
Table 2. Summary of manufacturing planning and control literature in ETO reviewed [16]

\begin{tabular}{|c|c|c|c|}
\hline Topic & Author(s) & Methodology & Approaches and Solutions \\
\hline \multirow{2}{*}{$\begin{array}{l}\text { Framework, problems, } \\
\text { and implementation } \\
(\mathrm{MRP}, \mathrm{ERP} \text {,and MRPII) }\end{array}$} & Jin et al. (1995) & Conceptual & $\begin{array}{l}\text { Proposed a new MRP framework in } \\
\text { ETO environment }\end{array}$ \\
\hline & $\begin{array}{l}\text { Bertnard and } \\
\text { Muntslag (1993) }\end{array}$ & $\begin{array}{l}\text { Literature } \\
\text { review and } \\
\text { conceptual }\end{array}$ & $\begin{array}{l}\text { Contradiction of MRP II and ETO } \\
\text { environment, a new framework }\end{array}$ \\
\hline \multirow{2}{*}{$\begin{array}{l}\text { Web-based SCM and } \\
\text { MPC }\end{array}$} & Kehoe and & Simulation & eSCM for planning and control \\
\hline & $\begin{array}{l}\text { and 2001b); } \\
\text { Caglinao et al. } \\
\text { (2003) }\end{array}$ & & \\
\hline \multirow[t]{2}{*}{$\begin{array}{l}\text { Computer-aided produc- } \\
\text { tion management issues }\end{array}$} & $\begin{array}{l}\text { Hicks and Brai- } \\
\text { den, (2000) }\end{array}$ & $\begin{array}{l}\text { Conceptual } \\
\text { and simula- } \\
\text { tion }\end{array}$ & $\begin{array}{l}\text { MPC issues in capital goods indus- } \\
\text { try, applicability of MRP II }\end{array}$ \\
\hline & $\begin{array}{l}\text { Gosling and } \\
\text { Naim (2009) }\end{array}$ & $\begin{array}{l}\text { Literature } \\
\text { review }\end{array}$ & Robust definition of SCM in ETO \\
\hline Overview of MPC & Gelders, (1991) & $\begin{array}{l}\text { Literature } \\
\text { review and } \\
\text { conceptual }\end{array}$ & $\begin{array}{l}\text { Review of new MPC concepts, } \\
\text { Planning approach to monitor } \\
\text { capacity, lead times in ETO }\end{array}$ \\
\hline \multirow[t]{5}{*}{$\begin{array}{l}\text { Integrated planning and } \\
\text { scheduling }\end{array}$} & $\begin{array}{l}\text { Little et al. } \\
(2000)\end{array}$ & $\begin{array}{l}\text { Multiple case } \\
\text { study }\end{array}$ & $\begin{array}{l}\text { MPC challenge in ETO companies, } \\
\text { ETO planning and scheduling } \\
\text { reference model }\end{array}$ \\
\hline & $\begin{array}{l}\text { Samaranayake } \\
\text { and } \quad \text { Toncich } \\
(2007)\end{array}$ & $\begin{array}{l}\text { Conceptual } \\
\text { and simula- } \\
\text { tion }\end{array}$ & Integrated ERP and SCM \\
\hline & $\begin{array}{l}\text { Caron et al. } \\
(1995)\end{array}$ & Conceptual & $\begin{array}{l}\text { Developed a project management } \\
\text { model, Integrating manufacturing } \\
\text { and innovative processes }\end{array}$ \\
\hline & Yeo et al. (2006) & Conceptual & $\begin{array}{l}\text { Managing projects in synchroniza- } \\
\text { tion }\end{array}$ \\
\hline & $\begin{array}{l}\text { Rahman et al. } \\
(2003)\end{array}$ & $\begin{array}{l}\text { Literature } \\
\text { and Concep- } \\
\text { tual }\end{array}$ & $\begin{array}{l}\text { Framework to establish design and } \\
\text { manufacturing for ETO companies }\end{array}$ \\
\hline
\end{tabular}




\section{$5 \quad$ Project Manufacturing Planning and Control}

PMPC is a modification of the well-known MPC framework developed by [19] to the project manufacturing environment. The framework illustrates the planning processes in project manufacturing and their interconnection (refer Fig. 1). The proposed framework, when implemented in an MPC environment, will act as a decision support system and can serve as a foundation of further work to be carried in this area. In project MPC, the demand management function covers the management of sales order lines and defines either project groups as "planning groups" or single projects for these orders based on the resemblance between different orders. The demand management process is carried out in collaboration with engineering management tools where preliminary design and configuration activities are performed. When the detailed engineering activities are further accomplished in time, the project schedule and tasks are updated and customized parts/ items are specified. Projects and tasks create demands for specific parts/ items, and eventually these demand items requests for resources.

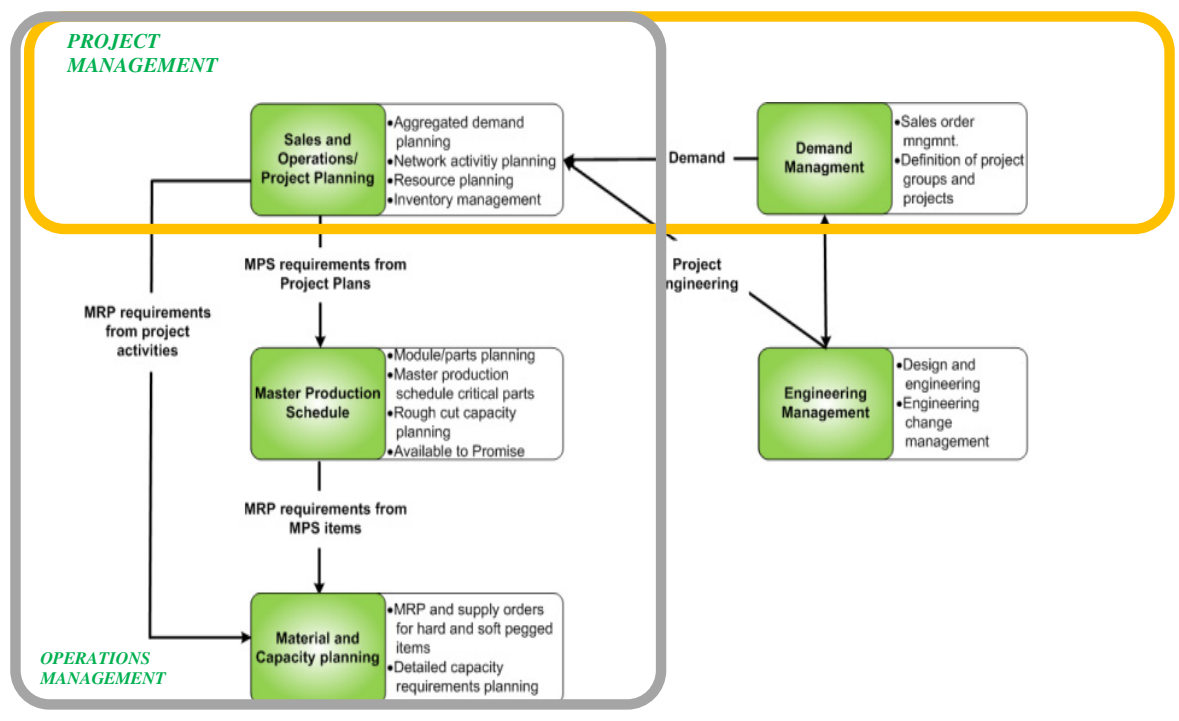

Fig. 1. Project planning and control (PMPC)

Aggregated demands planning for these main parts are done on the sales and operations planning function. Since the project environment requires a network of subcontractors, suppliers, and outsourcers, network activity planning, namely subcontracting and operation rates, should be identified on this overall planning function. Further a resource capacity check should be made on this level as well. Project tasks are then pegged to demand items/ parts related to each task and these demand parts/ items are also pegged to the assigned capacities. Master production scheduling is performed on modules that are defined in the product structure. This planning process 
is useful in project manufacturing for the planning of long lead time parts and subassemblies that require preproduction or need to be ordered in advance. Material requirement planning is controlled by different reservation levels that are assigned to items or item groups. Some items are project specific, some can be assigned to project groups, while some can be identified as common supply, meaning that, they can be used by all projects and project groups. When the detailed capacity is checked against the plans, the production and purchasing orders are placed.

When an engineering change request is received from the customer, project MPC system can be used to aid changes related to material management and respective adjustments on the project schedule. This can be enabled by its pegging logic. Having linked the orders with the supplies, activities, and project schedule, it facilitates change propagation of the engineering change request in an integrated and automated manner. Then, these changes can automatically adjust the project schedule by the pegging functionality which is enabling the linkage between materials and activities. Hence, the updated schedule can up-date the timing, budget, and cost, which can be either used to negotiate with the customer or for control purposes.

\section{Conclusion and Future Work}

ETO companies face many challenges for effective and efficient management of MPC. By means of this paper we aim to provide main contribution to theory by proposing a conceptual framework to under-stand project manufacturing planning and control. The framework will be useful for ETO companies in their ERP development and tendering practices by defining the methods and functionality that are required for efficient planning and control in ETO environments. The research has limitations due to the relatively scarce literature and lack of empirical study and evidences. However it reaches its main objective by increasing the theoretical knowledge in this field and building a framework for further study and applications. The framework will be further developed in collaboration with the Norwegian offshore supplier industry and the research projects "The Norwegian Manufacturing Future" (SFI NORMAN) and "PowerUp". The main limitations are related to the study's conceptual nature, and further research is required to investigate the appropriateness of the suggested approaches and techniques in practice.

\section{References}

1. Alderman, N., Braiden, P.M., Hills, W., Maffin, D., Thwaites, A., Vaughan, R.: Business process analysis and technological change in the capital goods industry. International Journal of Computer Applications in Technology 6, 418-427 (1998)

2. Bertrand, J.W.M., Muntslagd, R.: Production control in engineer to order firms. Int.J. Prod. Econ. 30, 3-22 (1993)

3. Braiden, P.M., Alderman, N., Thwaites, A.T.: Engineering design and product development and its relationship to manufacturing: A programme of case study research in British companies. International Journal of Production Economics 30-31, 265-272 (1993) 
4. Gosling, J., Naim, M.M.: Engineer-to-order supply chain management: A literature review and research agenda. International Journal of Production Economics 122, 741-754 (2009)

5. Hicks, C., Braiden, P.: Computer-aided production management issues in the engineer-toorder production of complex capital goods explored using a simulation approach. International Journal of Production Research 38, 4783-4810 (2000)

6. Hicks, C., Mcgovern, T., Earl, C.: Supply chain management: A strategic issue in engineer to order manufacturing. International Journal of Production Economics 65, 179-190 (2000)

7. Hicks, C., Mcgovern, T., Earl, C.F.: A typology of UK engineer-to-order companies. International Journal of Logistics 4, 43-56 (2001)

8. Hicks, C., Song, D.P., Earl, C.F.: Dynamic scheduling for complex engineer-to- order products. Int. J. of Prod. Research 45(15), 3477-3503 (2007)

9. Hopp, W.J., Roof, M.L.: Setting WIP levels with Statistical Throughput Control (STC) in CONWIP production lines. International Journal of Production Research 36, 867-882 (1998)

10. Land, M.J., Gaalman, G.: Workload control concepts in job shops - a critical assessment. International Journal of Production Economics 46, 535-548 (1996)

11. Little, D., Rollins, R., Peck, M., Porter, J.K.: Integrated planning and scheduling in the engineer-to-order sector. International Journal of Computer Integrated Manufacturing 13, $545-554$ (2000)

12. Sower, V.E., Abshire, R.D.: Successful implementation of advanced manufacturing technology: a cross sectional survey. International Journal of Computer Applications in Technology 16, 12-20 (2003)

13. Spearman, M.L., Hogg, G.L.: Production rates, flow times and work in process levels in a generalized pull production system. Manuscript, Department of Industrial Engineering and Management Sciences, Northwestern University, Evanstin IL, Department of Industrial Engineering, Texas A\&M University (1986)

14. Spearman, M., Woodruff, D., Hopp, W.: CONWIP: a pull alternative to kanban. International Journal of Production Research 28, 879-894 (1990)

15. Stevenson, M., Hendry, L.C., Kingsman, B.G.: A review of production planning and control: the applicability of key concepts to make -to-order industry. Int. J. of Prod. Res. 43(5), 869-898 (2005)

16. Stevenson, M., Hendry, L.C.: Aggregate load-oriented workload control: A review and a re-classification of a key approach. International Journal of Production Economics 104, 676-693 (2006)

17. Sriram, P.K., Alfnes, E., Arica, E.: Manufacturing planning and control functionalities in engineer-to-order companies: an investigation of challenges and existing solutions. In: IWAMA 2012, Trondheim, Norway (2012)

18. Suri, R.: Quick Response Manufacturing. A Companywide Approach to Reducing Lead Times. Productivity Press (1998)

19. Vollmann, T.E., Berry, W.L., Whybark, D.C., Jacobs, R.F.: Manufacturing Planning and Control for Supply Chain Management (2005)

20. Wahlers, J.L., Cox, J.F.: Competitive factors and performance measurement: applying the theory of constraints to meet customer needs. International Journal of Production Economics 37, 229-240 (1994) 